\section{Effect of petrol and spent oil on the growth of Guinea Corn (Sorghum bicolor L.)}

\author{
Ronke Justina Komolafe, ${ }^{1}$ Olatunde M. \\ Akinola, ${ }^{2}$ Oludare James Agbolade ${ }^{1}$ \\ ${ }^{1}$ Department of Plant Science and \\ Biotechnology, Federal University, Oye \\ Ekiti; ${ }^{2}$ Department of Cell Biology and \\ Genetics, University of Lagos, Nigeria
}

\section{Abstract}

This study assessed the effect of petrol and spent lubricating oil on the major growth traits (such as root length, stem length, leaf area, and biomass), and the changes in epidermal layer of leaf and its mitotic index in Guinea Corn (Sorghum bicolor L.) exposed to 0\% (control), $5 \%, 10 \%, 15 \%$ and $20 \%$ concentrations of petrol and spent lubricating oil. Each concentration was mixed with $3 \mathrm{~kg}$ of soil in a plastic pot and each treatment was carried out in three replicates. Forty days after planting, the leaf areas of guinea corn plant were $95.83 \mathrm{~cm}^{2}$, $89.67 \mathrm{~cm}^{2}, 89.47 \mathrm{~cm}^{2}$, and $77.80 \mathrm{~cm}^{2}$ in control, $5 \%, 10 \%, 15 \%$, and $20 \%$ respectively of petrol pollutant. The means of stem length were $32.50 \pm 0.5 \mathrm{~cm}, 22.60 \pm 0.65 \mathrm{~cm}, 21.27 \pm 0.75 \mathrm{~cm}$, $20.83 \pm 0.28 \mathrm{~cm}$ and $20.33 \pm 0.28 \mathrm{~cm}$ in control, $5 \%, 10 \%, 15 \%$ and $20 \%$ respectively. Both leaf area and stem length of treated seedlings reduced with increased concentration of the pollutants. Additionally, reduction in the dry weight of the seedlings increased with increasing concentration of both petrol and spent oil. The micrograph of the internal anatomy of the upper epidermal layers of the leaf revealed broken and scattered epidermal cells and smaller sizes of the stomata, and were increased with the increasing concentration of the treatment. Statistical analysis of the treatment shows that there was a significant reduction $(\mathrm{P}<0.05)$ in the stem length and leaf area of the seedlings. This study revealed that petroleum pollutant adversely affected germination, growth and development of guinea corn but petroleum products like spent oil can provide nutrition necessary for growth and yield of plant at low concentration.

\section{Introduction}

Crude oil pollutants are highly stable compounds persisting in the environment for a long time before they can be broken down. ${ }^{1}$ They accumulate in tissues of most fauna and flora life, poisoning and causing a wide range of toxic effect on them. Oil pollutants include aviation fuel, engine oil, petrol, spent oil and diesel. The extent to which the environment is polluted by these oils depend on the frequency and severity of the spills in a given area. ${ }^{2}$ Oil pollution is associated with highly toxic heavy metals such as cadmium, zinc, lead, chromium, nickel and manganese with great negative effects on plants. ${ }^{3}$ Different heavy metals at optimal concentrations have been shown to inhibit various metabolic processes in plants resulting in their reduced growth and development. ${ }^{4}$ Plants may be killed by oil pollution or suffer reduced growth and reproductive rates due to combination of physical coating, altered soil chemistry and toxic effects of crude oil components. ${ }^{5}$ Noticeable forms of stunted growth and chlorosis in plants and also marked anatomical change in plant tissues are responses to heavy metal toxicity. ${ }^{6}$ Oil spillage on land retards vegetative growth for a period of time and in extreme cases, leads to the destruction of vegetation. It also increases potential for hazards and renders the soil unfit for cultivation. Any hydrocarbon solvent is liable to penetrate into plants through lipophilic surface, roots and once inside, it dissolves the cell membranes and cause loss of cell sap and in some cases, accumulates in the tissue of fruits of crops. ${ }^{7}$ Particularly, dangerous soil contamination includes pollution with petroleum derivatives, which is very often observed in municipal soils around industrial plant and in areas where petroleum and natural gas are obtained. ${ }^{8}$

Bioaccumulation of hydrocarbons in plant appears to be related to the lipid content of the plant tissue, the greater the hydrocarbon accumulation. ${ }^{9}$ Plants may be killed by oil pollution or suffer reduced growth and reproductive rates due to combination of physical coating, altered soil chemistry and toxic effects of crude oil components. ${ }^{5}$ The contamination of soil environment can undoubtedly limit its protective function, upset metabolic activity, unfavorably affect its physicochemical characteristics, reduce fertility and negatively influence plant production. ${ }^{10}$ The above features are very much influenced by anthropogenic factors, which include the contamination of soil with petroleum derived products. Changes in some soil properties resulting from contamination with petroleum derived substances, and particularly those related to physic-chemical composition, brings about some changes in the biological composition of soil which in consequence, can lead to water and oxygen deficits, as well as to a shortage of available forms of nitrogen and phosphorus. ${ }^{10}$

Since contamination of soil with refinery products deteriorates its biochemical and physiochemical properties, it also limits the growth and development of plants, whose nutritive and technological value can be low and often questionable. In this connection,
Correspondence: Ronke Justina Komolafe, Department of Plant Science and Biotechnology, Federal University of Oye, Oye-Ekiti, Ekiti State, Nigeria. Tel.: +23.4813 .8106512 .

E-mail: ronke.komolafe@fuoye.edu.ng

Key words: Biomass; mitotic index; seedlings; pollutant; micrograph; anatomy.

Contributions: RJK and OMA designed the experiment; RJK carried out the experiment and wrote the initial draft; 0JA reviewed the paper and made necessary correction.

Conflict of interest: the authors declare no potential conflict of interest.

Received for publication: 21 February 2015.

Revision received: 2 April 2015.

Accepted for publication: 2 April 2015.

This work is licensed under a Creative Commons Attribution NonCommercial 3.0 License (CC BYNC 3.0).

(C) Copyright R.J. Komolafe et al., 2015

Licensee PAGEPress srl, Italy

International Journal of Plant Biology 2015; 6:5883 doi:10.4081/pb.2015.5883

this present study has been undertaken to determine the effect of soil contamination with petrol and spent oil on the growth of guinea corn. The major objectives of this research were to study: i) the effect of petrol and spent oil pollutants on the growth traits (such as root length, stem length, leaf area and biomass) of guinea corn; ii) their effect on the changes in epidermal layer of Guinea Corn leaf; iii) their effect on the mitotic index of Guinea Corn leaf.

\section{Materials and Methods}

\section{Seeds procurement and germina- tion experiment}

The seeds of Guinea Corn (Sorghum bicolor L.) were procured from the market in Lagos and its viability was tested. Three $\mathrm{kg}$ of soil sample was weighed and put inside plastic buckets. The soil in each bucket was treated with $5 \%, 10 \%, 15 \%$, and $20 \%$ concentrations of petrol and spent lubricating oil. Another plastic bucket containing soil did not receive any treatment with petrol and spent lubricating oil; this serves as control. Each treatment was then replicated three times. Five seeds of guinea corn were sown into the soil in the plastic buckets. The soil in the plastic buckets was regularly watered to ensure that the soil was moist enough for plant germination. 


\section{Determination of biomass}

Fresh and dry weights of each seedling were determined. This was carried out by measuring the weight of the fresh leaf in each treatment using a weighing balance. The dry weights of the air dried leaves were also determined. This was done by oven-drying the leaves at $80 \pm 5^{\circ} \mathrm{C}$ for 48 hours.

\section{Determination of leaf area}

The leaf areas of the samples were calculated according to the method of Pearcy et al. ${ }^{11}$ using the formula: $\mathrm{LA}=\mathrm{L} \times W$, where $\mathrm{L}$ represents the length of the leaf and $W$ the width of the leaf. The leaf was placed on a plain sheet of paper, the length and the width of the leaf was then measured using a ruler.

\section{Determination of the leaf lower and upper epidermal layers}

Plant samples were cut into smaller pieces with the sharp razor blade and were placed inside the glass Petri dishes. Twenty $\mathrm{cm}^{3}$ of concentrated nitric acid was carefully added into each glass Petri dishes to cover the small pieces of plant samples. The glass Petri dishes were covered with their lids and kept in a safe place for 48 hours to enable the concentrated nitric acid to start the bleaching and detachment of the mesophyll layer between the lower and the upper epidermal layers. The process was completed as soon as the greenish coloration of the leaves turned to light-yellow coloration. After the bleaching, the plant samples were carefully removed from the glass petri dishes and washed in tap water to remove the traces of the acid.

The concentration of nitric acid inside the specimen containers were replaced with tap water, the plant samples were then returned into it using a dissecting needle and were kept in a safe place for 24 hours. The separation of the lower and upper epidermal layers commenced as soon as bubbles of water was seen forming on top of the plant samples. Pieces of the separated layers were seen floating on top of tap water inside the specimen container.

\section{Preparation of root tip for mitotic indices}

Each root concentration was fixed in a specimen bottle using acetic acid alcohol. The root in each concentration was placed on a clean plain glass slide using a forceps and a razor blade was used in cutting its tip $5 \mathrm{~mm}$ long and the remaining parts discarded. A drop of normal $\mathrm{HCl}$ was used to dehydrate and soften its tissue for maceration for 2 minutes. The excess normal $\mathrm{HCl}$ was neatly removed with filter paper. A dissecting needle was then used to macerate the root tip after which a drop of acetic orcein stain was placed on the tissue to stain for 15-20 minutes.
After staining the tissue, the specimen on the slide was gently covered with a cover slip, the stain was allowed to spread evenly over the square parts of the cover slip without a bubble. The slide with the specimen was then placed in between two folds of the filter paper and using the blunt end of biro, gentle tapping and pressure was applied around the square area of the cover slip for evenly squashing of the specimen.

Finally, the square edges of the cover slip or squashed slide was sealed with the white transparent nail hardener. This was then viewed under the microscope to observe its mitotic stages and chromosomal aberrations for photomicrographs.

\section{Determination of soil $\mathrm{pH}$}

The soil PH was determined following the method of Eckert et al. ${ }^{12}$ The soil samples were first air dried and $5 \mathrm{~g}$ of the air-dried soil was mixed with $5 \mathrm{~mL}$ of distilled water and stirred. The mixture was allowed to stand for thirty minutes to allow it to settle. The slurry was decanted into a test tube. A portable $\mathrm{pH}$ meter with combine glass and calomel electrode was put into the slurry. The $\mathrm{pH}$ meter was standardized with buffer solutions of $\mathrm{pH} 4.0$, 7.0 and 9.2 and the $\mathrm{pH}$ read off.

\section{Results}

\section{Germination experiment}

Table 1 shows the percentage germination of guinea corn under different treatment. Germination of seeds begins 4 days after planting in control and treated seeds. The percentage of seeds germinated varies according to the concentrations of the petroleum products. On the fifth and eighth day of planting, $45 \%$ and $85 \%$ germination were recorded. In $5 \%$ concentration of petrol, $45 \%$ germination was recorded five days after treatment, $25 \%$ germi- nation was recorded in $10 \%$. Germination then increased till the eighth day to $50 \%, 25 \%, 20 \%$ and $15 \%$ in pot treated with $5 \%, 10 \%, 15 \%$ and $20 \%$ concentrations respectively while in the control experiment, $85 \%$ were recorded eighth day after planting. These values were maintained respectively till the fortieth day. From these values, it was observed that the rate of germination was lower in the treated experiment than in control. It was also observed that with increase in concentration, percentage germination reduced for the treated experiment. For sample treated with 5\% spent oil, percentage germination on the fifth day was $15 \%, 30 \%, 15 \%$ and $5 \%$ in sample treated with $5 \%, 10 \%, 15 \%$ and $20 \%$ concentrations of spent oil. In the control experiment the percentage germination was $85 \%$ and this was maintained throughout the experiment.

Comparing the rate of germination of seed with the different concentrations of petrol and spent oil, it was discovered that germination was slower in sample treated with spent oil than in petrol (Table 1).

\section{Fresh and dry weight}

Table 2 shows the effect of the petrol and spent oil pollutants on fresh weight and dry weight of the seedlings sown in different concentrations of the pollutants and control. The control has the greater value of fresh and dry weight of $3.7 \mathrm{~g}$ and $0.43 \mathrm{~g}$ respectively with loss of $3.36 \mathrm{~g}$. In $5 \%$ petrol treated plant, the fresh weights $0.97 \mathrm{~g}$ and the dry weight is $0.20 \mathrm{~g}$ with a loss of $0.77 \mathrm{~g}$, there is $0.45 \mathrm{~g}$ and $0.26 \mathrm{~g}$ fresh weights; $0.06 \mathrm{~g}$ and $0.04 \mathrm{~g}$ dry weights of plant treated with $15 \%$ and $20 \%$ petrol respectively. The trend shows a decrease in fresh weight and dry weight with increasing concentration of petrol pollutant. In seeds treated with spent oil pollutants, there is a decrease from $0.97 \mathrm{~g}$ of fresh weight to $0.19 \mathrm{~g}$ of dry weight with loss of $0.78 \mathrm{~g}$ from seed treated with $5 \%$ concentration. The seed treated with $10 \%$ concentration has high value of fresh weight of $1.53 \mathrm{~g}$, dry weight of $0.20 \mathrm{~g}$ with a loss of $1.33 \mathrm{~g}$. The value

Table 1. Percentage germination of seeds of Guinea corn in different concentrations of petrol (in days).

\begin{tabular}{lccccc} 
Days after treatment & Control & $5 \%$ petrol & $\mathbf{1 0 \%}$ petrol & $\mathbf{1 5 \%}$ petrol $\mathbf{2 0 \%}$ petrol \\
4 & 45 & 25 & 20 & 15 & 10 \\
5 & 55 & 35 & 25 & 20 & 15 \\
\hline 6 & 65 & 35 & 25 & 20 & 15 \\
7 & 75 & 40 & 25 & 20 & 15 \\
\hline 8 & 85 & 50 & 25 & 20 & 15 \\
9 & 85 & 55 & 25 & 20 & 15 \\
\hline 10 & 85 & 60 & 30 & 20 & 15 \\
11 & 85 & 60 & 30 & 25 & 20 \\
\hline 12 & 85 & 60 & - & 25 & 20 \\
\hline
\end{tabular}


decreased to $0.80 \mathrm{~g}$ fresh weight and $0.11 \mathrm{~g}$ of dry weight with loss of $0.69 \mathrm{~g}$ in $15 \%$ concentration. Twenty percent concentration had a fresh weight value of $0.40 \mathrm{~g}, 0.05 \mathrm{~g}$ dry weight with a loss of $0.35 \mathrm{~g}$.

\section{Growth parameters}

Stem length characteristics

Table 3 shows the effect of different concentration of the pollutants on the stem length of the seedlings of guinea corn. The control seedlings were observed to have the highest stem length of $32.50 \pm 0.50 \mathrm{~cm}$ compared with the $20 \%$ concentration of petrol with the lowest mean stem length of $20.33 \pm 0.28 \mathrm{~cm}$ as observed 40 days after planting. The stem length increased with time (in days) in each treatment concentration while it decreased with increased concentration. Statistical analysis revealed that the treatment effect were highly significant $(\mathrm{P}<0.05)$ on the stem length of guinea corn.

\section{Leaf-area characteristics}

Table 4 shows the effect of different concentrations of petrol and spent oil pollutants on the leaf area of experimental seedlings of guinea corn. Leaf area increased with time (in days) in each treatment whereas it decreased as the concentration of the pollutant increased except $10 \%$ concentration of spent oil whose leaf area is greater than its $5 \%$ concentration as shown in Figure 1. The largest leaf area was observed on the $40^{\text {th }}$ day in the control with a leaf area of $95.83 \mathrm{~cm}^{2}$ compared with the least leaf area of $16.83 \mathrm{~cm}^{2}$ in $20 \%$ concentration of spent oil. The spent oil had greater effect on the leaf area of plants having the smallest leaf areas were significant $(\mathrm{P}<0.05)$ for all treated seeds. It was observed that in petrol pollutant, the mean leaf area decreases as the concentration of treatment increases from control $\left(95.833 .51 \mathrm{~cm}^{2}\right)$ to $(77.80)$ at $20 \%$ concentration as shown in Figure 1A, while in spent oil pollutant, the leaf area increases at $10 \%$ concentration even more than the control $\left(29.33 \pm 0.76 \mathrm{~cm}^{2}\right)$ and decrease to $(16.83 \pm 0.57$ $\mathrm{cm}^{2}$ ) at $20 \%$ concentration at $40^{\text {th }}$ day of planting as shown in Figure 1B. It was shown that the mean difference of the spent oil is significant at the 0.05 level $(\mathrm{P}<0.05)$.

\section{Mitotic index}

The results of the mitotic indices of guinea corn plant are shown in Table 5. This shows the number of dividing cells and the mitotic index of the one thousand cells counted. 35 of the counted cells were found to be dividing in the control with the mitotic index of 3.5 . The $5 \%$ concentration of petrol has the highest dividing cell with the mitotic index of 2.5. It was observed that the greater the concentration of the petrol pollutant, the

Table 2. The effect of petrol and spent oil pollutants on the fresh and dry weight of guinea corn seedlings.

\begin{tabular}{lccc} 
Concentration & Fresh weight & Dry weight & Difference in weight (weight loss) \\
Control & 3.79 & 0.43 & 3.36 \\
$5 \%$ petrol & 0.97 & 0.20 & 0.77 \\
\hline $10 \%$ petrol & 0.90 & 0.11 & 0.82 \\
$15 \%$ petrol & 0.45 & 0.06 & 0.39 \\
\hline $20 \%$ petrol & 0.26 & 0.04 & 0.22 \\
$5 \%$ spent oil & 0.97 & 0.19 & 0.78 \\
\hline $10 \%$ spent oil & 1.53 & 0.20 & 1.33 \\
$15 \%$ spent oil & 0.80 & 0.11 & 0.69 \\
\hline $20 \%$ spent oil & 0.40 & 0.05 & 0.35
\end{tabular}

Table 3. Mean of the stem length of Guinea Corn seedlings in petrol and spent oil pollutants.

\begin{tabular}{|c|c|c|c|c|c|c|c|c|c|c|}
\hline Days after treatment & Control & $5 \%$ & $\begin{array}{l}\text { Petrol } \\
10 \%\end{array}$ & $15 \%$ & $20 \%$ & Control & $5 \%$ & $10 \%$ & $\begin{array}{c}\text { Spent oil } \\
15 \%\end{array}$ & $20 \%$ \\
\hline 5 & $4.57 \pm 0.40$ & $3.22 \pm 8.73$ & $2.92 \pm 0.10$ & $2.70 \pm 0.17$ & $1.93 \pm 0.40$ & $5.53 \pm 5.77$ & $4.17 \pm 0.20$ & $4.77 \pm 0.23$ & $3.07 \pm 0.40$ & $2.90 \pm 0.65$ \\
\hline 10 & $6.40 \pm 0.10$ & $5.89 \pm 0.19$ & $4.50 \pm 0.50$ & $4.17 \pm 0.20$ & $3.73 \pm 0.20$ & $7.90 \pm 0.60$ & $7.10 \pm 0.10$ & $7.89 \pm 7.63$ & $4.43 \pm 0.37$ & $4.07 \pm 0.11 y$ \\
\hline 15 & $10.23 \pm 0.25$ & $8.27 \pm 0.25$ & $8.07 \pm 0.11$ & $7.83 \pm 0.35$ & $7.10 \pm 0.17$ & $10.80 \pm 0.26$ & $9.33 \pm 0.28$ & $10.80 \pm 0.17$ & $7.47 \pm 0.61$ & $7.30 \pm 0.43$ \\
\hline 20 & $14.50 \pm 0.50$ & $10.77 \pm 0.25$ & $10.00 \pm 0.50$ & $9.50 \pm 0.50$ & $8.18 \pm 0.27$ & $14.50 \pm 0.50$ & $12.67 \pm 0.28$ & $16.00 \pm 0.50$ & $11.33 \pm 0.76$ & $10.33 \pm 0.76$ \\
\hline 25 & $16.67 \pm 5.77$ & $14.17 \pm 0.28$ & $13.33 \pm 0.76$ & $12.40 \pm 0.17$ & $12.50 \pm 0.50$ & $18.50 \pm 0.50$ & $14.80 \pm 0.26$ & $20.17 \pm 0.28$ & $14.17 \pm 0.28$ & $14.00 \pm 0.50$ \\
\hline 30 & $21.73 \pm 0.25$ & $17.15 \pm 0.18$ & $16.27 \pm 0.25$ & $15.83 \pm 0.28$ & $15.17 \pm 0.28$ & $20.50 \pm 0.50$ & $17.17 \pm 0.28$ & $22.13 \pm 0.32$ & $16.17 \pm 0.28$ & $15.83 \pm 0.28$ \\
\hline 35 & $26.33 \pm 0.28$ & $20.73 \pm 0.40$ & $19.83 \pm 0.28$ & $17.83 \pm 2.02$ & $18.27 \pm 0.25$ & $22.00 \pm 0.50$ & $18.47 \pm 0.45$ & $25.50 \pm 0.50$ & $18.00 \pm 0.50$ & $17.57 \pm 0.40$ \\
\hline 40 & $32.50 \pm 0.50$ & $22.60 \pm 0.65$ & $21.27 \pm 0.75$ & $20.83 \pm 0.28$ & $20.33 \pm 0.28$ & $24.50 \pm 0.50$ & $21.50 \pm 0.50$ & $29.33 \pm 0.76$ & $20.83 \pm 0.28$ & $20.00 \pm 0.50$ \\
\hline
\end{tabular}

Table 4. Effect of different concentrations of petrol and spent oil on the leaf area of Guinea corn.

\begin{tabular}{|c|c|c|c|c|c|c|c|c|c|c|}
\hline \multirow{2}{*}{ Days after treatment } & \multicolumn{5}{|c|}{ Petrol } & \multicolumn{5}{|c|}{ Spent oil } \\
\hline & Control & $5 \%$ & $10 \%$ & $15 \%$ & $20 \%$ & Control & $5 \%$ & $10 \%$ & $15 \%$ & $20 \%$ \\
\hline 5 & 5.70 & 1.87 & 1.28 & 1.10 & 1.08 & 4.90 & 2.47 & 3.37 & 1.96 & 1.85 \\
\hline 10 & 9.18 & 6.11 & 5.15 & 4.73 & 3.82 & 5.92 & 5.93 & 6.07 & 5.36 & 4.68 \\
\hline 15 & 21.50 & 14.55 & 9.97 & 9.73 & 9.52 & 9.37 & 8.89 & 13.77 & 8.63 & 7.37 \\
\hline 20 & 40.50 & 30.00 & 25.00 & 17.83 & 16.67 & 11.50 & 10.65 & 20.00 & 10.00 & 9.50 \\
\hline 25 & 50.50 & 45.40 & 37.60 & 35.50 & 33.85 & 13.85 & 12.00 & 21.33 & 11.00 & 10.67 \\
\hline 30 & 60.50 & 56.50 & 51.33 & 46.17 & 45.83 & 15.17 & 12.83 & 24.50 & 12.02 & 11.18 \\
\hline 35 & 84.83 & 73.67 & 70.67 & 70.33 & 64.17 & 18.50 & 15.50 & 26.00 & 15.00 & 14.33 \\
\hline 40 & 95.83 & 90.47 & 89.67 & 89.47 & 77.80 & 20.00 & 17.33 & 29.33 & 17.33 & 16.83 \\
\hline
\end{tabular}


lower the number of dividing cells and mitotic index. In spent oil pollutant, the number of dividing cells increased in $10 \%$ concentration with 2.0 mitotic index and lowest in $20 \%$ concentration with 1.1 mitotic index. This shows that the greater the concentration of the pollutants, the lower the mitotic indices and number of dividing cell of guinea corn.

\section{Upper epidermal layer (adaxial)}

The micrograph of the upper and lower epidermal layer of guinea corn leaf at different concentration of the pollutant is shown in Figure 2.

\section{Discussion}

Toxic effect of petrol and spent oil pollutants were evaluated on germination pattern, stem length, leaf area, root growth, dry and fresh weight. The effect on the internal morphology of the tissues of guinea corn plant and the mitotic indices of guinea corn were also investigated. Germination rate was low in $20 \%$ concentration of spent oil during the fifth day of planting of the seeds. It has moderate percentage of germination at $10 \%$ concentration of spent oil at day twelve of planting while there
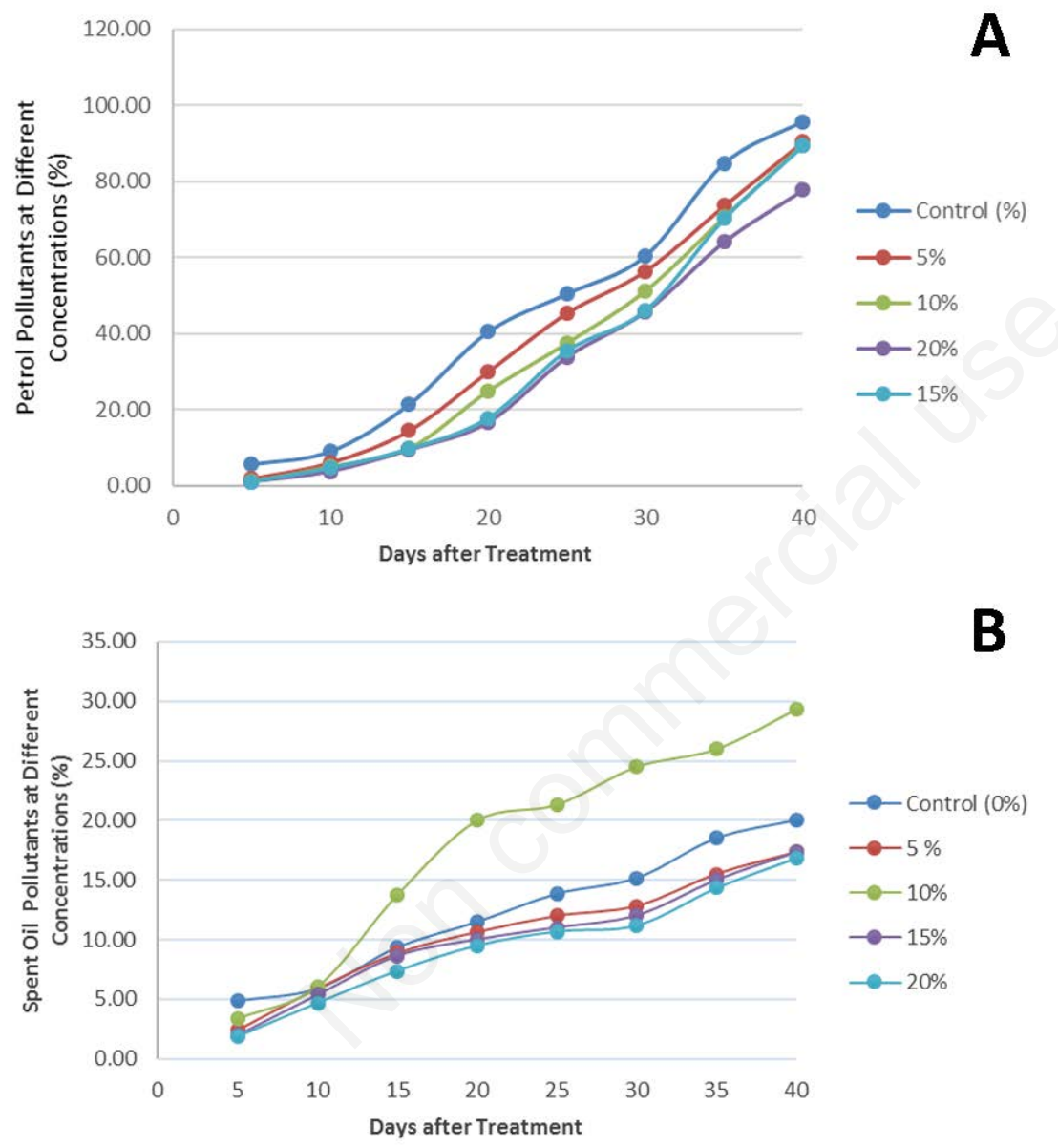

Figure 1. Graph of A) petrol pollutant and B) spent oil against days after treatment.

Table 5. Effect of petroleum products on the mitotic indices of Guinea corn.

\begin{tabular}{lccccc} 
& Control & $5 \%$ & $10 \%$ & $15 \%$ & $20 \%$ \\
Petrol & & & & & \\
No of cells counted & 1000 & 1000 & 1000 & 1000 & 1000 \\
No of dividing cells & 35 & 25 & 24 & 19 & 12 \\
Mitotic index & 3.5 & 2.5 & 2.4 & 1.9 & 1.2 \\
Spent oil & & & & & \\
No of cells counted & 1000 & 1000 & 1000 & 1000 & 1000 \\
No of dividing cells & 35 & 19 & 20 & 14 & 11 \\
Mitotic index & 3.5 & 1.9 & 2.0 & 1.4 & 1.1 \\
\hline
\end{tabular}

was moderately low percentage germination at $5 \%$ concentration of petrol at day twelve of planting. The low rate of germination was probably due to toxicity resulting from pollutant contamination around the seeds. ${ }^{13}$ Low rate of germination agrees with the findings of Dulta and Boissyna, ${ }^{14}$ who worked on the effect of paper mill effluent on germination of rice seed and growth behavior of its seedlings discovered that pollutants particularly at higher concentration inhibit germination. Arora and Chauhan, ${ }^{15}$ reported in their investigation that the effect of tannery effluent on seed varieties of Hordeum vulgaris L. showed that the effluent caused a significant reduction in germination percentage.

Stem length decreased with increase in concentration in all seeds treated with the petrol pollutant. This is in accordance with the findings of Ramasubramanian et al. ${ }^{16}$ who discovered that seedling length of Phaseolus mungo grown in sand culture decreased with an increase in concentration of effluents obtained from match dye industries. In spent oil pollutant, the stem length of seeds treated with $10 \%$ concentration of spent oil is greater than other and even the control experiment. This is in accordance with the findings of Agbogidi et $a l .{ }^{17}$ who showed that the effect of crude oil pollution on plants is dependent on the level of pollution and that small amounts of minerals oils and oil products may actually be beneficial to plants.

Due to the toxic effect of the pollutant, there was reduction in fresh and dry weight with increase in concentration of both petrol and spent oil, except in seedlings treated with $10 \%$ spent oil which experiences an increase in dry weight and wet weight due to nutrient accumulation at that concentration. At high concentration of the pollutants, there was low fresh and dry weight of the seedlings. This is in agreement with that of Ramasubramanian et al., ${ }^{16}$ who showed that there was a decrease in plant dry weight at high concentration of industrial effluent. Arora Rajini et al. ${ }^{15}$ also observed a significant reduction in the total biomass in almost all the varieties of Hadeum vulgare $\mathrm{L}$.

The micrograph of the internal anatomy of the upper and lower epidermal layers shows the effect of the pollutant at various concentration on the arrangement of the epidermal cells. The higher concentration of the pollutants is responsible for the broken and scattered epidermal cells and smaller sizes of the stomata. The effect of petrol and spent oil on the mitotic indices of guinea corn shows that the mitotic index is high at low concentration of petrol and it is a little higher in $10 \%$ concentration spent oil. This shows that a high concentration of petrol pollutant affect the growth of the root and thereby affecting the mitotic index of the plant. 


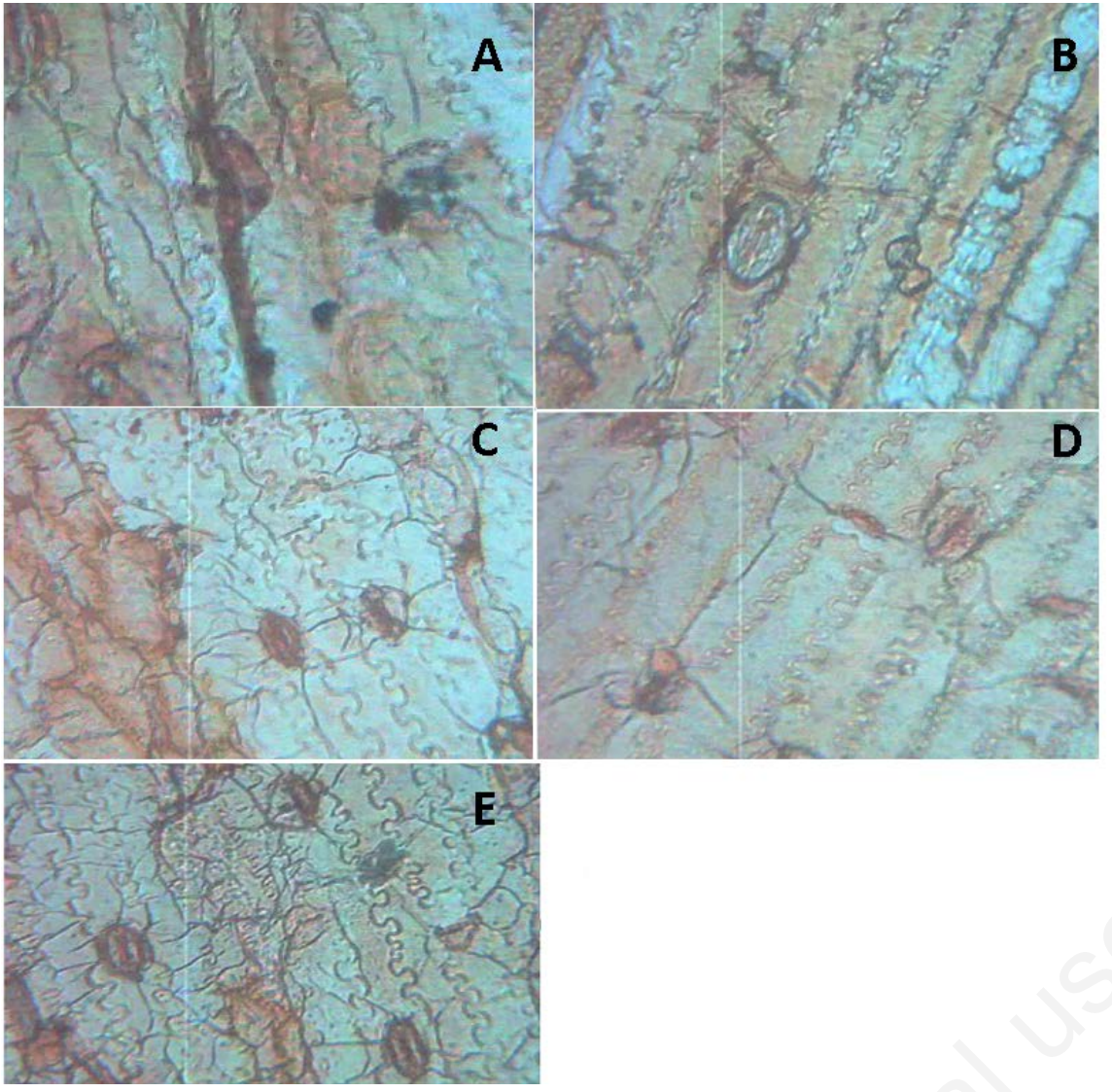

Figure 2. A) Upper epidermal layer guinea corn leave exposed to 5\% petrol; B) upper epidermal layer guinea corn leave exposed to $10 \%$ petrol; C) Upper epidermal layer of guinea corn leave unexposed (control); D) upper epidermal layer guinea corn leave exposed to $20 \%$ petrol; E) upper epidermal (Adaxial) layer guinea corn leave exposed to $20 \%$ spent oil.

\section{Conclusions}

This study revealed that petroleum pollutant adversely affected germination, growth and development of guinea corn. The damage done to the plant at higher concentration of the pollutant is more severe than at a lower concentration. However, petroleum products like spent oil can provide nutrition necessary for growth and yield of plant at low concentration. The petrol and spent oil pollutants affected the internal anatomy of the upper and lower epidermal layer of guinea corn leaf. The higher concentration of the pollutants is responsible for the broken and scattered epidermal cells and smaller sizes of the stomata. The high concentration of the pollutants also affected the growth of the root and thereby affecting the mitotic index of the plant.

This result clearly presents the effect of petrol and spent oil on the growth of Guinea

1. Lastmer SD, Darall MS, Thomas CD, Ellgoard EG. Dendo chronology and heavy metal deposition in tree rings. $\mathrm{J}$ Environ Qual 1996;25:1411-9.

2. Bragg DC, ed. Oil spill simulation 2nd International Oil Spill Research and Development forum, London; 1995.

3. Davies MS. Effects of toxic concentration of metals on the root growth and development. In: Alkinson D, ed. Plant root growt. London: Blackwell; 1991. pp 211-227.

4. Bala R, Setia RC. Some aspect of Lead toxicity in plants. New Dehli: Narendia
5. Leighton FA. Petroleum oils and wildlife. 2000. Available from: http://fr.cwhcrcsf.ca/wildlife_health_topics/oil.htm

6. Cox PE, Christensen JC, McGrath SP. Speciation of cadmium and zinc with application to soil solution. J Environ Qual 1995;24:183-90.

7. Gallagher D, ed. Current status of the environmental health program. Second international oil spill research and developmental forum. 23-26 May 1995, London.

8. Adam G, Gamoh K, Morris DG, Duncan H. Effect of alcohol addition on the movement of petroleum hydrocarbon fuels in soil. Sci Total Environ 2002;286:15-25.

9. Edwards NT. Polycyclic aromatic hydrocarbons (PAH) in the terrestrial environment. A review. J Environ Qual 1983;12:427-41.

10. Wyszkowski M, Wyszkowska J, Ziokowska A. Effect of soil contamination with diesel oil on yellow lupine yield and macro-element content. Plant, Soil Environment 2004;50:218-26.

11. Pearcy R, Ehleringer J, Mooney H, Rundel P. Plant physiological ecology: methods and instrumentation. London: Chapman and Hall; 1989.

12. Eckert D, Sins TJ. Recommended soil pH and lime requirement tests recommended soil testing procedures for the Northeastern United States. p. 11-16. In Sims JT, Wolf A (eds.). Recommended soil testing procedures for the Northeastern United States. Northeast Regional Bulletin \#493. Agricultural Experiment Station, University of Delaware, Newark, USA.

13. Komolafe RJ. Effect of petrol and spent oil on the growth of Guinea corn (Sorghum bicolour L.) Lagos: University of Lagos; 2009.

14. Duita SK, Boissyna CL. Effect of paper mill effluents on germination of rice seed (Oryza sativa L. Var. masuri) and growth behaviour of its seedling. J Industrial Pollut Control 1997;13:41-7. Publishing House; 1990.
15. Arora R, Chauhan S. Effect of tannery effluent on seed germination and total biomass in some varieties of Hordeum vulgare L. Acta Ecologica 1996;18:112-55.

16. Ramasubramanian S. Analysis of industrial effluent and their impact on the growth and metabolism of Phaseola mungo L. Commun Soil Sci Plant Analysis 1993;24:2241-9.

17. Agbogidi OM, Eruotor PG, Akparobi SO. Effect of time of application of crude oil to soil on the Growth of maize (Zea mays). Res J Environ Toxicol 2007;1:116-23. 